\title{
Prostaglandin F and 13,14-dihydro-15-keto prostaglandin $F$ in the endometrium and uterine flushings of sheep before implantation
}

\author{
J. K. Findlay, Noelene Colvin, J. Swaney and B. Doughton \\ Medical Research Centre, Prince Henry's Hospital, St Kilda Road, Melbourne, Victoria 3004, \\ Australia
}

\begin{abstract}
Summary. The concentrations of prostaglandin F (PGF) and its major metabolite, 13,14-dihydro-15-keto prostaglandin F-2 $\alpha$ (PGFM), were measured in caruncular and intercaruncular endometrium of pregnant and non-pregnant ewes on Days 9,11,13 and 15 after mating (Day 0) and related to the content of PGF and PGFM in the uterine flushings. The tissue concentrations of PGF and PGFM increased with time after mating particularly on Days 13 and 15 and to a greater extent in pregnancy. However, the ratio of PGF to PGFM remained constant at $0 \cdot 7$, except on Day 15 in non-pregnant endometrium when it fell to $0.3(P<0.05)$, suggesting that synthesis rather than metabolism was limiting tissue concentrations of PGs.

The changes in tissue concentrations of PGF and PGFM were reflected in the contents of PGF and PGFM in the uterine flushings of non-pregnant, but not pregnant ewes. Pregnant ewes had relatively more PGF and less PGFM than did non-pregnant ewes on Day 15. Moreover, there was always 5-10-fold less PGFM than PGF in the uterine flushings. It is concluded that the increase in PG in the uterine lumen in pregnancy has its origin in the blastocyst, and that pregnancy may be associated with an increase in the synthesis and retention of PGs in the endometrium, rather than a redistribution towards the uterine lumen away from the uterine venous drainage.
\end{abstract}

\section{Introduction}

There must be extension of the life span of the corpus luteum to establish and maintain early pregnancy in the ewe. This requires a signal from an embryo in the uterus 12-13 days after mating (Moor, 1968), 4-5 days before attachment (Boshier, 1969). There is good evidence that prostaglandin (PG) F-2 $\alpha$ of uterine origin is the agent responsible for regression of the corpus luteum of non-pregnant sheep (Goding, 1974; Inskeep \& Murdoch, 1980).

The sheep embryo may counteract the luteolytic action of uterine PGF- $2 \alpha$ in several ways. It may alter the synthesis, release and metabolism of PGF-2 $\alpha$ by the uterus, the transport of PGF- $2 \alpha$ from the uterus to the ovary, or it may counteract the luteolytic action of PGF-2 $\alpha$ at the ovarian level (Inskeep \& Murdoch, 1980; Baird, Abel, Brown, Kelly \& Wilmut, 1981; Findlay, 1981).

Endometrial concentrations of PGF-2 $\alpha$ and PGE-2 are increased from Days 13 to 17 in pregnant compared to non-pregnant ewes and there is an increase in PGE-2 relative to PGF-2 $\alpha$ (Lewis et al., 1977; Ellinwood, Nett \& Niswender, 1979; Baird et al., 1981; Findlay et al., 1981). Evidence for changes in the concentration of PGF-2 $\alpha$ and PGE- 2 in the uterine vein and secretion by the uterus of pregnant ewes is contradictory (Inskeep \& Murdoch, 1980; Baird et al., 1981; 
Findlay, 1981). The ability of endometrium to synthesize PGs in vitro was either increased (Ellinwood et al., 1979) or not affected by pregnancy on Day 15 (Findlay et al., 1981). There is evidence of an increase in PGF and PGE-2 content of the uterine lumen between Days 13 and 17 of pregnancy (Ellinwood, et al., 1979) which could originate from the blastocyst (Hyland, Manns \& Humphrey, 1982). Therefore, the increased uterine tissue and luminal content of PGF in pregnancy could reflect changes in release and metabolism of PGF by both the endometrium and the blastocyst.

Very little attention has been paid to the metabolism of PG by uterine tissues of sheep in early pregnancy. A major stable metabolite of PGF-2 $\alpha$ is 13,14 dihydro-15-keto-PGF-2 $\alpha$ (PGFM) which is present in peripheral blood of non-pregnant ewes (Peterson, Tervit, Fairclough, Havik \& Smith, 1976; Louis, Parry, Robinson, Thorburn \& Challis, 1977) and is formed mainly in the lung (Davis, Fleet, Harrison \& Maule Walker, 1980), although caruncular endometrium has the capacity to form PGFM in vitro (Louis et al., 1977). Pregnant ewes do not have the pulsatile increases in PGFM concentration observed in peripheral blood of non-pregnant ewes from 13 to 17 days after mating (Peterson et al., 1976). Although this may reflect decreased release of PGF-2 $\alpha$ by the uterus, it does raise the possibility that there is decreased metabolism of PGF- $2 \alpha$ to PGFM by endometrial tissue and/or increased accumulation of PGFM in the uterine tissues and lumen, in addition to PGE-2 and PGF-2 $\alpha$ (Ellinwood et al. 1979).

The aim of this study was to determine the tissue concentrations of PGF and PGFM in caruncular and intercaruncular endometrium of pregnant and non-pregnant ewes from Day 9 to 15 , and to relate these to the content of PGF and PGFM in the uterine lumen.

\section{Materials and Methods}

\section{Tissues}

Details of the animals and the collection of uterine flushings and tissues are given in Exp. 1 of Findlay, Clarke, Swaney, Colvin \& Doughton (1982). Briefly, tissues from 4-7 pregnant and 4-7 non-pregnant Corriedale ewes were analysed on each of Days 9,11,13 and 15. At laparotomy the uterine lumen was flushed in situ with $20 \mathrm{ml}$ Medium 199 (CSL, Melbourne, Australia) containing $1 \mu \mathrm{g}$ indomethacin $/ \mathrm{ml}$ and $400 \mathrm{U}$ benzyl penicillin $/ \mathrm{ml}, 1000 \mathrm{U}$ neomycin sulphate $/ \mathrm{ml}$ and $2000 \mathrm{U}$ polymycin B sulphate/ml (CSL, Melbourne, Australia). The uterine flushings were centrifuged $\left(2000 \mathrm{~g}, 10 \mathrm{~min}, 4^{\circ} \mathrm{C}\right)$ to remove the blastocysts and debris and the supernatant stored at $-15^{\circ} \mathrm{C}$ until assayed for prostaglandin. The tract was removed and caruncular endometrium was dissected on ice from intercaruncular endometrium within $20 \mathrm{~min}$. Tissue samples for PG analysis were placed in $2 \mathrm{ml}$ ice-cold assay buffer (see below), acidified to $\mathrm{pH} 3.5$ with $0.1 \mathrm{M}$-citrate buffer and containing $1 \mu \mathrm{g}$ indomethacin $/ \mathrm{ml}$ (Findlay et al., 1981). Samples were kept at $4^{\circ} \mathrm{C}$ until extracted within $2 \mathrm{~h}$.

To extract the prostaglandins, the tissues were homogenized in methanol $(0.6 \mathrm{~g} / 5 \mathrm{ml}$; Univar AR, Ajax Chemicals, Sydney, Australia) after the addition of 1000 c.p.m. $\left(\sim 5\right.$ pg) $\left[{ }^{3} \mathrm{H}\right] \mathrm{PGF}-2 \alpha$ to determine methodological losses $(\sim 80 \%$ recovery). The methanolic extract was centrifuged and the tissue re-extracted. The pooled methanolic extracts were dried under air at $40^{\circ} \mathrm{C}$ and the residue was dissolved in assay buffer $(0.01 \mathrm{M}-\mathrm{Tris}-\mathrm{HCl}, \mathrm{pH} 7 \cdot 4$ containing $0.1 \% \mathrm{w} / \mathrm{v}$ gelatin, $0.154 \mathrm{M}-\mathrm{NaCl}$ and $0.01 \%$ thiomersal; Sigma, Missouri, U.S.A.).

\section{Radioimmunoassays}

Reference standards (Upjohn, Kalamzoo, U.S.A.) were stored at $-20^{\circ} \mathrm{C}$ in ethanol. Tritiated PGF- $2 \alpha\left(\left[5,6,8,9,11,12,14,15-{ }^{3} \mathrm{H}(\mathrm{N})\right] \mathrm{PGF}-2 \alpha ; 555 \times 10^{10} \mathrm{~Bq} / \mathrm{mmol}\right)$ and PGFM $\left(\left[5,6,8,9,11,12,14-{ }^{3} \mathrm{H}(\mathrm{N})\right] 13,14\right.$ dihydro-15 keto-PGF- $\left.2 \alpha ; 259 \times 10^{10} \mathrm{~Bq} / \mathrm{mmol}\right)$ were obtained from NEN (Massachussetts, U.S.A.) and stored at $-20^{\circ} \mathrm{C}$ in ethanol or ethanol : water $(7: 3, v / v)$. 
For assay, standards and tracers were dried down under $\mathrm{N}_{2}$ and redissolved in assay buffer. Separation of bound and free ligand was achieved by incubating with $0.3 \%(\mathrm{w} / \mathrm{v})$ charcoal (Merck, Darmstaadt, Germany) containing $0.03 \%$ (v/v) Dextran T70 (Pharmacia, Uppsala, Sweden) at $4{ }^{\circ} \mathrm{C}$ for 15 (PGFM) or 20 (PGF) min and centrifuging for $30 \mathrm{~min}$ at $1500 \mathrm{~g}$. The data and assay characteristics were computed according to the method of Burger, Lee \& Rennie (1972).

$P G F$. The antiserum was raised in a rabbit against PGF- $2 \alpha$ conjugated to keyhole limpet haemocyanin; Bleed B was used at a final dilution of $1 / 25000$. The cross-reactivity of this antiserum, using $\left[{ }^{3} \mathrm{H}\right]$ PGF- $2 \alpha$ as tracer, was: PGF- $2 \alpha(100 \%)$, PGF- $1 \alpha(139 \%)$, PGE-1 and PGFM $(1.4 \%), 15-$ keto-PGF- $2 \alpha$ and PGE-2 $(1.3 \%)$, PGA $(1.2 \%)$, arachidonic acid $(0.5 \%)$ and PGB-2 $(<0.01 \%)$. The data are expressed in terms of PGF due to the cross-reaction with PGF-1 $\alpha$.

Unknown tissue extracts and uterine flushings were routinely assayed at several dilutions and were parallel to the standard curve (e.g. tissue, $y=-21.92 x+121 \cdot 4$; flushings, $y=-21.83 x+$ $125 \cdot 7$; standards, $y=-18 \cdot 10 x+120 \cdot 8$ and $y=-18 \cdot 37 x+126 \cdot 1$, respectively). For 9 assays, the mean \pm s.e.m. non-specific binding was $2.8 \pm 1.0 \%$, and the sensitivity was $3.0 \pm 0.2 \mathrm{pg} /$ tube. The solvent blank was routinely below the sensitivity of the assay. The within-assay coefficient of variation $(\mathrm{CV})$ was $<15 \%$ between 15 and $200 \mathrm{pg} /$ tube with a minimum of $9.9 \pm 0.7 \%$. The between-assay CV was $13 \cdot 1 \%$ at $232 \pm 10 \mathrm{pg} /$ tube and $18 \cdot 3 \%$ at $385 \pm 23 \mathrm{pg} /$ tube.

$P G F M$. The antiserum, raised in a rabbit against PGFM conjugated to keyhole limpet haemocyanin, was used at a final dilution of $1 / 30000$. The cross-reactivity of this antiserum, using $\left[{ }^{3} \mathrm{H}\right]-$ PGFM as tracer, was: PGFM $(100 \%), 15$-keto-PGF- $2 \alpha(3.6 \%)$, PGB-2 $(0.8 \%)$, PGF- $1 \alpha(0.05 \%)$, PGF-2 $\alpha$, PGE-1, PGE-2 and PGA-1 $(<0.01 \%)$. Dilutions of uterine flushings, extracted or unextracted, were parallel to the standard curve (unextracted flushings, $y=-23 \cdot 38 x \pm 182$; standard, $y=-21.97 x \pm 136$ ). Samples were therefore not routinely extracted but were assayed at several dilutions. The mean sensitivity was $2.3 \pm 0.3 \mathrm{pg} /$ tube for 5 assays. The within-assay $\mathrm{CV}$ was $<15 \%$ between 12 and $230 \mathrm{pg} /$ tube, with a minimum of $9 \cdot 4 \pm 0.4 \%$. The between-assay CV was $17 \cdot 4 \%$ at $50 \cdot 2 \pm 3 \cdot 6 \mathrm{pg} /$ tube.

Dilutions of tissue extracts were parallel to the standard curve (tissue, $y=-19 \cdot 74 x+121 \cdot 7$; standard, $y=-22.29 x+112.9$ ). The mean sensitivity was $1.9 \pm 0.3 \mathrm{pg} /$ tube for 8 assays and the solvent blank was routinely below this value. The within-assay $\mathrm{CV}$ was $<15 \%$ between 7 and 360 $\mathrm{pg} /$ tube with a minimum of $6 \cdot 2 \pm 0.4 \%$. The between-assay $\mathrm{CV}$ was $11 \cdot 1 \%$ at $28.6 \pm 1 \cdot 1 \mathrm{pg} /$ tube, $7 \cdot 1 \%$ at $59 \cdot 2 \pm 1 \cdot 5$ and $10 \cdot 6 \%$ at $136 \cdot 3 \pm 5 \cdot 1$.

\section{Statistical analyses}

The data for PGF, PGFM and the ratios were analysed without transformation. Comparisons within days and within tissues between pregnant and non-pregnant ewes were made by independent $t$ test with the d.f. ranging from 8 to 12. Comparisons within days, within pregnancy status, between caruncular and intercaruncular tissues were made by dependent $t$ test with the d.f. ranging from 8 to 12 . Comparisons between days, within tissues and pregnancy status were made by one-way analysis of variance with Duncan's multiple range $F$ test, with total d.f. ranging from 18 to 22 , of which 3 were attributable to days and 15-19 were attributable to animals.

\section{Results}

\section{Endometrial concentrations of $P G F$ and $P G F M$}

The concentrations of PGF did not differ between caruncular and intercaruncular endometrium within days and pregnancy status (Table $1 \mathrm{a}$, dependent $t$ test, $P>0.05$ ). The concentrations of PGF in caruncular and intercaruncular tissues were significantly higher in pregnant than in non-pregnant ewes on Days 13 and 15 (except in intercaruncular tissues on Day 15), but not on Days 9 and 11 (Table 1a). In non-pregnant ewes, PGF concentrations in both types 
Table 1. Concentrations of prostaglandin F (PGF) and 13,14-dihydro-15-keto prostaglandin F-2 $\alpha$ (PGFM) (ng/g) and the ratio of PGF/PGFM in caruncular and intercaruncular endometrium of pregnant $(\mathrm{P})$ and non-pregnant $(\mathrm{NP})$ ewes

\begin{tabular}{|c|c|c|c|c|c|}
\hline \multirow{2}{*}{$\begin{array}{l}\text { Endometrial } \\
\text { tissue }\end{array}$} & \multirow{2}{*}{$\begin{array}{l}\text { Pregnancy } \\
\text { status }\end{array}$} & \multicolumn{4}{|c|}{ Day after mating } \\
\hline & & 9 & 11 & 13 & 15 \\
\hline \multirow{2}{*}{\multicolumn{6}{|c|}{$\begin{array}{l}\text { (a) } P G F \\
\text { Intercaruncular }\end{array}$}} \\
\hline & NP & $81 \pm 46(5)$ & $144 \pm 37$ & $218 \pm 43^{* *}(5)$ & $262 \pm 83(7)$ \\
\hline & $\mathrm{P}$ & $120 \pm 47^{a}(5)$ & $147 \pm 31^{a}(7)$ & $438 \pm 43^{\mathrm{ab}}(5)$ & $515 \pm 152^{b}(6)$ \\
\hline \multirow[t]{2}{*}{ Caruncular } & NP & $126 \pm 46(5)$ & $216 \pm 62(4)$ & $151 \pm 33^{* *}(5)$ & $162 \pm 46^{*}(7)$ \\
\hline & $\mathbf{P}$ & $176 \pm 64^{c}(5)$ & $111 \pm 47^{\circ}(7)$ & $573 \pm 97^{d}(5)$ & $403 \pm 93^{d}(6)$ \\
\hline \multicolumn{6}{|l|}{ (b) $P G F M$} \\
\hline \multirow[t]{2}{*}{ Intercaruncular } & NP & $119 \pm 36^{e}(5)$ & $204 \pm 55^{\mathrm{ef}}(4)$ & $490 \pm 104^{r}(5)$ & $427 \pm 123^{f}(5)$ \\
\hline & $\mathbf{P}$ & $195 \pm 63^{9}(5)$ & $274 \pm 44^{9}(7)$ & $614 \pm 66^{\mathrm{h}}(4)$ & $657 \pm 85^{\text {h }}(4)$ \\
\hline \multirow[t]{2}{*}{ Caruncular } & NP & $158 \pm 54(5)$ & $342 \pm 83(4)$ & $275 \pm 35^{*}(5)$ & $396 \pm 96(5)$ \\
\hline & $\mathbf{P}$ & $256 \pm 34^{i}(5)$ & $201 \pm 45^{1}(7)$ & $662 \pm 54^{j}(4)$ & $647 \pm 118(4)$ \\
\hline \multicolumn{6}{|l|}{ (c) $P G F: P G F M$} \\
\hline Intercaruncular & $\begin{array}{l}\mathrm{NP} \\
\mathrm{P}\end{array}$ & $\begin{array}{l}0.68 \pm 0.18(5) \\
0.60 \pm 0.09(5)\end{array}$ & $\begin{array}{l}0.78 \pm 0.19(4) \\
0.56 \pm 0.11(7)\end{array}$ & $\begin{array}{l}0.48 \pm 0.09(5) \\
0.67 \pm 0.05(4)\end{array}$ & $\begin{array}{l}0.36 \pm 0.07^{*}(5) \\
0.70 \pm 0.15(4)\end{array}$ \\
\hline \multirow[t]{2}{*}{ Caruncular } & NP & $0.77 \pm 0.19$ & $0.61 \pm 0.13$ & $0.61 \pm 0.20$ & $0.28 \pm 0.06^{*}(5)$ \\
\hline & $\mathbf{P}$ & $0.62 \pm 0.13(5)$ & $0.50 \pm 0.09(7)$ & $0.78 \pm 0.15(4)$ & $0.64 \pm 0.16(4)$ \\
\hline
\end{tabular}

Values are mean \pm s.e.m. for the no. of ewes in parentheses.

${ }^{*} P<0.05,{ }^{* *} P<0.005$, non-pregnant versus pregnant tissue within day (independent $t$ test).

a-i Numbers in rows with different superscripts differ at the $5 \%$ level of significance by Duncan's $F$ test.

of endometrial tissues did not differ significantly $(P>0.05)$ between Days 9 and 15 (Table 1a; intercaruncular, $\mathrm{F}_{3.17}=1.569 ;$ caruncular, $\mathrm{F}_{3.17}=0.532$ ). However, in pregnant ewes, there were significant increases in tissue concentrations of PGF by Day 13-15 (Table 1a; intercaruncular, $\mathrm{F}_{3.19}=5.40, P<0.05 ;$ caruncular, $\mathrm{F}_{3.19}=7.83, P<0.01$ ).

The concentrations of PGFM did not differ between caruncular and intercaruncular endometrium within days and pregnancy status (Table $1 \mathrm{~b}$, dependent $t$ test, $P>0.05$ ). The concentration of PGFM was higher $(P<0.05$, independent $t$ test $)$ in pregnant than in non-pregnant caruncular endometrium only on Day 13. There were no significant effects of pregnancy on PGFM concentrations in intercaruncular endometrium. In non-pregnant ewes, PGFM concentrations increased significantly on Days 13 and 15 in intercaruncular endometrium $\left(F_{3,15}=3.91, P<0.05\right)$ but not in caruncular endometrium $\left(\mathrm{F}_{3,15}=2.21, P>0.05\right)$. However, in pregnant ewes, there were increases in PGFM concentration on Days 13 and 15 in both caruncular $\left(\mathrm{F}_{3,16}=15 \cdot 36, P<\right.$ $0.01)$ and intercaruncular endometrium $\left(\mathrm{F}_{3.16}=13.46 ; P<0.01\right)$.

The ratios of concentrations of PGF to PGFM were always < 1 (Table 1c). On Days 9-13 the mean ratios were similar $(P>0.05)$ in endometrial tissues of both pregnant and non-pregnant ewes, and ranged from 0.48 to 0.78 . On Day 15 , the ratio of PGF to PGFM fell to around 0.3 in nonpregnant ewes, compared with 0.7 in pregnant ewes $(P<0.05)$.

\section{Prostaglandin content of uterine flushings}

After injecting $20 \mathrm{ml}$ medium into the uterine lumen, $16.1 \pm 1.1 \mathrm{ml}$ (mean \pm s.d.) were recovered from pregnant ewes and $16.7 \pm 0.8 \mathrm{ml}$ from non-pregnant ewes.

On Day 9, the PGF content of uterine flushings of pregnant and non-pregnant ewes was approximately $1 \mathrm{ng}$ (Table 2). Thereafter, the levels increased to between 30 and $40 \mathrm{ng}$ on Days 11 and 13 and again there were no differences between pregnant and non-pregnant animals. However, by Day 15 there was approximately 4-fold more PGF in the uterine flushings of pregnant (354 $\mathrm{ng}$ ) than non-pregnant ewes $(77 \mathrm{ng})(P<0 \cdot 05)$. The PGFM content of uterine flushings in pregnant 
Table 2. The PGF and PGFM content (ng) and ratio in uterine flushings of pregnant (P) and nonpregnant (NP) ewes

\begin{tabular}{|c|c|c|c|c|c|}
\hline \multirow[b]{2}{*}{ PG } & \multirow{2}{*}{$\begin{array}{l}\text { Pregnancy } \\
\text { status }\end{array}$} & \multicolumn{4}{|c|}{ Day after mating } \\
\hline & & 9 & 11 & 13 & 15 \\
\hline PGF & $\begin{array}{l}P \\
N P\end{array}$ & $0.91 \pm 0.06^{\mathrm{a}}$ & $39.60 \pm 14.34^{b}$ & $\begin{array}{l}35.96 \pm 3.50^{\mathrm{b}} \\
46.73+9.04 \mathrm{e}\end{array}$ & $353.7 \pm 111.9^{c}$ \\
\hline PGFM & $\begin{array}{l}\mathrm{P} \\
\mathrm{NP}\end{array}$ & $\begin{array}{l}1.37 \pm 0.09^{f} \\
1.81 \pm 0.38^{h}\end{array}$ & $\begin{array}{l}1.79 \pm 0.46^{f} \\
2.32 \pm 0.60^{f}\end{array}$ & $\begin{array}{l}1.31 \pm 0.26^{\mathrm{f}} \\
3.16 \pm 0.85^{\mathrm{h} *}\end{array}$ & $\begin{array}{l}4.04 \pm 0.83^{9} \\
9.78 \pm 3.15^{i}\end{array}$ \\
\hline PGF : PGFM & $\begin{array}{l}\mathrm{P} \\
\mathrm{NP}\end{array}$ & $\begin{array}{l}0.67 \pm 0.01^{i} \\
0.60 \pm 0.07^{m}\end{array}$ & $\begin{array}{l}18 \cdot 0 \pm 4 \cdot 0^{k} \\
29 \cdot 7 \pm 19 \cdot 2^{n}\end{array}$ & $\begin{array}{l}30 \cdot 6 \pm 5 \cdot 1^{k} \\
16 \cdot 9 \pm 2 \cdot 8^{n *}\end{array}$ & $\begin{array}{l}95 \cdot 5 \pm 32 \cdot 0^{1} \\
11 \cdot 6 \pm 4 \cdot 1^{n *}\end{array}$ \\
\hline
\end{tabular}

Values are mean \pm s.e.m. for $4-5$ ewes per group.

a-n Numbers in rows with different superscripts differ at the $5 \%$ level of significance by Duncan's $F$ test.

${ }^{*} P<0.05$, non-pregnant versus pregnant tissue (independent $t$ test).

and non-pregnant ewes was similar on Days 9,11 and 13 (Table 2). There was a significant increase in PGFM content by Day 15, in pregnant and non-pregnant ewes, the increase tending to be more marked in non-pregnant than in pregnant ewes.

An examination of the ratio of PGF to PGFM in uterine flushings (Table 2) revealed a relative increase in PGF over PGFM after Day 9 , with the increase being even greater $(P<0.05)$ in pregnant ewes on Days 13 and 15.

\section{Discussion}

The increases in PGFM concentration in caruncular and intercaruncular endometrial tissues with days after mating and particularly in pregnancy paralleled those of PGF described in earlier studies (Wilson, Butcher \& Inskeep, 1972; Lewis et al., 1977; Ellinwood et al., 1979; Findlay et al., 1981). The presence of PGFM in the ovine endometrium reflects the 15 -hydroxy dehydrogenase and reductase activities previously demonstrated in vitro in caruncular endometrium (Louis et al., $1977)$ and in separated epithelial and stromal cells of the ovine endometrium (O, Findlay, Colvin, Swaney \& Doughton, 1983).

Because PGs are not thought to be stored in tissues, but result from the rapid metabolism of free arachidonic acid (Bito, 1975), the endogenous concentrations of PGF and PGFM reported in this study could reflect synthesis from endogenous arachidonic acid released by the trauma of tissue collection (McCracken, 1980). To minimize this possibility, we used procedures to avoid PG synthesis during homogenization as described in the 'Methods'. Furthermore, there is evidence to show that trauma has a reduced influence on the release of PGF in the pregnant uterus, probably because the pregnant endometrium is unable to respond to oxytocin, the agent believed to be responsible for inducing PG release after trauma (McCracken, 1980). Finally, there is a good correlation between the concentration of PG in a tissue and its ability to synthesize PG when incubated in vitro (Ellinwood et al., 1979; Findlay et al., 1981).

The ratio of PGF to PGFM in endometrial tissues remained around 0.7 except in non-pregnant endometrium on Day 15 when it fell to $0 \cdot 3$. This suggests that synthesis rather than metabolism of PGF was the limiting factor in pregnant and non-pregnant endometrial tissues, but it does not exclude the possibility of decreased metabolism in pregnancy. The increased endometrial concentration of PGF during the late luteal phase of the cycle is thought to result from increased synthetase activity rather than availability of substrate (Horton \& Poyser, 1976). Huslig, Fogwell \& Smith (1979) demonstrated a 3-fold increase in the specific activity of cyclo-oxygenase in microsomes from caruncular endometrium on Day 14, but not in microsomes from intercaruncular endometrium or myometrium. They inferred that this increase in cyclo-oxygenase activity occurred 
mainly in the stromal cells of the caruncular endometrium. However, both caruncular and intercaruncular endometrium can synthesize PGF in vitro (Alwachi, Bland \& Poyser, 1979; Findlay et al., 1981), with an increasing ability towards the end of the cycle (Alwachi et al., 1979). Dispersed caruncular and intercaruncular epithelial cells produced and metabolized more PGF than did a mixed population of stromal cells from the same tissues (O et al., 1983).

The higher tissue concentrations of PGF in pregnancy could reflect a number of factors such as more available substrate, increased synthetase activity, decreased metabolism or altered release from the tissue, or a contribution from the blastocyst to the total pool of PG. The in-vitro production of PGF was higher in random tissue slices of endometrium from pregnant than nonpregnant ewes (Ellinwood et al., 1979). In contrast, diced tissue from caruncular endometrium of pregnant ewes produced less PGF, but in the presence of excess arachidonic acid, there was no difference in the maximum ability of pregnant and non-pregnant endometrial tissues to synthesize PGF in vitro (Findlay et al., 1981). PGF and PGFM production by isolated endometrial epithelial cells of pregnant endometrium was less than that by similar cells from non-pregnant endometrium, when incubated in the absence of exogenous arachidonic acid (O et al., 1983). This implies that the release of endogenous arachidonic acid could be higher in pregnant than in non-pregnant endometrial tissues and that there might be co-operation in terms of supply of substrate between cell types in the endometrium for the synthesis and metabolism of PGs. The endometrium in pregnancy, unlike that in cyclic females, is continually exposed to progesterone after Day 14. Progesterone could increase the potential of the pregnant endometrium to release arachidonic acid, thus giving higher tissue concentrations of PGF. A similar situation has been postulated to account for the higher PG content but similar PG synthetase activities of secretory compared to persistent proliferative human endometrium (Smith, Abel, Kelly \& Baird, 1982).

The changes in endometrial concentrations of PGF and PGFM were reflected in the contents of the uterine lumen in pregnant but not in non-pregnant ewes. Also, there was 5-10-fold less PGFM than PGF in the lumen than in the endometrium. The large increase in PGF and PGE in uterine flushings of pregnant ewes (Ellinwood et al., 1979; this study) probably reflects the synthetic ability of the sheep blastocyst on Days 13-15 (Hyland et al., 1982) rather than transfer of PG from the endometrium and retention in the uterine lumen. The absence of a PG-binding protein in uterine flushings (Pope \& Stormshak, 1981) and evidence that the presence of a blastocyst and PGE-1 can reduce the flux of PGF into the uterine lumen of sheep at about this time (J. Nkuuke, J. G. Manns, P. F. Flood \& N. C. Rawlings, unpublished) supports this suggestion. The relatively low levels of PGFM in the uterine lumen may reflect the limited ability of the blastocyst to metabolize PGF (Maule Walker, Patik, Leaf \& Watson, 1977; Maule Walker \& Poyser, 1978; Lewis, Thatcher, Bazer \& Curl, 1982) or a rate of transfer of PGFM into the uterine lumen which differs from that of PGF. No evidence is available on this point.

In conclusion, these studies do not support the idea of a redistribution of endometrial prostaglandin into the uterine lumen as a mechanism of preventing luteolysis in pregnancy in the ewe (Findlay, 1981, 1983). There appears to be an overall increase as well as a relative change in endometrial concentrations of the respective prostaglandins during the preimplantation period of the ewe due to increased synthesis and retention in the endometrium and a contribution by the blastocyst. The importance of these changes in endometrial prostaglandins for the establishment of pregnancy remains to be elucidated.

This project was supported by the Australian Wool Research Trust Fund, the Ford Foundation and a Fellowship from the National Health and Medical Research Council of Australia (J.K.F.). The co-operation of the Director of the Animal Research Institute, Werribee, and the assistance of Sue Wilson and Gail Matthews is gratefully acknowledged. We thank Fay Lerman for secretarial assistance and Professor W. Walters, Department of Obstetrics and Gynaecology, Monash University, Melbourne, for the generous gift of PG antisera. 


\section{References}

Alwachi, S.N., Bland, K.P. \& Poyser, N.L. (1979) Uterine prostaglandin in $\mathrm{F}-2 \alpha$ and $\mathrm{E}-2$ production and content during the second half of the oestrous cycle of the sheep. Possible local control of the uterus by the ovary. Prostaglandins \& Medicine 3, 23-32.

Baird, D.T., Abel, M.H., Brown, A., Kelly, R.W. \& Wilmut, I. (1981) The synthesis and release of prostaglandins by the uterus during the oestrous cycle and early pregnancy. Colloque de la Societe national pour l'etude de la Sterilitie et de la Fecondite, Uterus et Fecondite, Biarritz, pp. 69-82. Masson, Paris.

Bito, L.Z. (1975) Are prostaglandins intracellular, transcellular or extracellular autocoids? Prostaglandins $\mathbf{9}$, 851-855.

Boshier, D.P. (1969) A histological and histochemical examination of implantation and early placentome formation in sheep. J. Reprod. Fert. 19, 51-62.

Burger, H.G., Lee, V.W.K. \& Rennie, G.C. (1972) A generalised computer program for the treatment of data from competitive protein-binding assays including radioimmunoassay. J. Lab. clin. Med. 80, 302312.

Davis, A.J., Fleet, I.R., Harrison, F.A. \& Maule Walker, F.M. (1980) Pulmonary metabolism of prostaglandin $\mathrm{F}-2 \alpha$ in the conscious non-pregnant ewe and sow. $J$. Physiol., Lond. 301, 86P, Abstr.

Ellinwood, W.E., Nett, T.M. \& Niswender, G.D. (1979) Maintenance of the corpus luteum of early pregnancy in the ewe. II. Prostaglandin secretion by the endometrium in vitro and in vivo. Biol. Reprod. 21, 845-856.

Findlay, J.K. (1981) Blastocyst-endometrial interactions in early pregnancy in the sheep. $J$. Reprod. Fert., Suppl. 30, 171-182.

Findlay, J.K. (1983) The endocrinology of the preimplantation period. In Pregnancy and Parturition, Vol. 4, Modern Trends in Endocrinology, pp. 35-67. Eds L. Martini \& V. James. Academic Press, New York.

Findlay, J.K., Ackland, N., Burton, R.D., Davis, A.J., Maule Walker, F.M., Walters, D.E. \& Heap, R.B. (1981) Protein, prostaglandin and steroid synthesis in caruncular and intercaruncular endometrium of sheep before implantation. J. Reprod. Fert. 62, 361377.

Findlay, J.K., Clarke, I.J., Swaney, J., Colvin, N. \& Doughton, B. (1982) Oestrogen receptors and protein synthesis in caruncular and intercaruncular endometrium of sheep before implantation. $J$. Reprod. Fert. 64, 329-339.

Goding, J.R. (1974) The demonstration that PGF-2 $\alpha$ is the uterine luteolysin in the ewe. J. Reprod. Fert. 38 , $261-271$.

Horton, E.W. \& Poyser, N.L. (1976) Uterine luteolytic hormone : a physiological role for prostaglandin $F-2 \alpha$. Physiol. Rev. 56, 595-651.

Huslig, R.L., Fogwell, R.L. \& Smith, W.L. (1979) The prostaglandin forming cyclo-oxygenase of ovine uterus: relationship to luteal function. Biol. Reprod. 25, 489-600.

Hyland, J.H., Manns, J.G. \& Humphrey, W.D. (1982) Prostaglandin production by ovine embryos and endometrium in vitro. J. Reprod. Fert. 65, 299-304.
Inskeep, E.K. \& Murdoch, W.J. (1980) Relation of ovarian functions to uterine and ovarian secretion of prostaglandins during the estrous cycle and early pregnancy in the ewe and cow. In Reproductive Physiology III, International Review of Physiology, Vol. 22, pp. 325-356. Ed. R. O. Greep. University Park Press, Baltimore.

Lewis, G.S., Wilson, L., Jr, Wilks, J.W., Pexton, J.E., Fogwell, R.L., Ford, S.P., Butcher, R.L., Thayne, W.V. \& Inskeep, E.K. (1977) PGF-2 $\alpha$ and its metabolites in uterine and jugular venous plasma and endometrium of ewes during early pregnancy. $J$. Anim. Sci. 45, 320-327.

Lewis, G.S., Thatcher, W.W., Bazer, F.W. \& Curl, J.S. (1982) Metabolism of arachidonic acid in vitro by bovine blastocysts and endometrium. Biol. Reprod. 27, $431-439$.

Louis, T.M., Parry, D.M., Robinson, J.S., Thorburn, G.D. \& Challis, J.R.G. (1977) Effects of exogenous progesterone and oestradiol on prostaglandin $F$ and 13,14-dihydro-15-oxo-prostaglandin $F$ and 13,14dihydro-15-oxo-prostaglandin F-2 $\alpha$ concentration in uteri and plasma of ovariectomized ewes. J. Endocr. 73, 427-439.

Maule Walker, F.M. \& Poyser, N.L. (1978) The metabolism of prostaglandins by the guinea-pig uterus with particular reference to corpus luteal maintenance in early pregnancy. Br. J. Pharmacol. 62, 177-183.

Maule Walker, F.M., Patik, C.E., Leaf, C.F. \& Watson, J. (1977) The metabolism of prostaglandins F-2 $\alpha$ and E-2 by non-pregnant porcine endometrial and luteal tissue and early pregnant porcine endometrial tissue, luteal tissue and conceptuses in vitro. Prostaglandins 14, 557-562.

McCracken, J.A. (1980) Hormone receptor control of prostaglandin F-2 $\alpha$ secretion by the ovine uterus. Adr. Prostaglandin Thromboxane Res. 8, 1329-1344.

Moor, R.M. (1968) Effect of embryo on corpus luteum function. J. Anim. Sci., Suppl. 1, 97-118.

O, W.S., Findlay, J.K., Colvin, N., Swaney, J. \& Doughton, B. (1983) In vitro prostaglandin production by isolated ovine endometrial cells. Clin. exp. Physiol. Pharmacol. Abstr. (in press).

Peterson, A.J., Tervit, H.R., Fairclough, R.J., Havik, P.G. \& Smith, J.F. (1976) Jugular levels of 13,14dihydro-15 keto-prostaglandin $F$ and progesterone around luteolysis and early pregnancy in the ewe. Prostaglandins 12, 551-558.

Pope, W.F. \& Stormshak, F. (1981) In-vitro binding of prostaglandin $F-2 \alpha$ to uterine luminal proteins of pregnant and non-pregnant ewes. J. Reprod. Fert. 63, $211-213$

Smith, S.K., Abel, M.H., Kelly, R.W. \& Baird, D.T. (1982) The synthesis of prostaglandins from persistent proliferative endometrium. $J$. clin. Endocr. Metab. 55, 284-289.

Wilson, L., Jr, Butcher, R.L. \& Inskeep, E.K. (1972) Prostaglandin F-2 $\alpha$ in the uterus of ewes during early pregnancy. Prostaglandins 1, 479482.

Received 20 October 1982 